\title{
IAMAS: a century of international cooperation in atmospheric sciences
}

\author{
Michael C. MacCracken ${ }^{1}$ and Hans Volkert ${ }^{2}$ \\ ${ }^{1}$ Climate Institute, 1201 New York Avenue NW, Suite 400, Washington D.C. 20005, USA \\ ${ }^{2}$ Deutsches Zentrum für Luft- und Raumfahrt e.V., Institut für Physik der Atmosphäre, \\ 82234 Oberpfaffenhofen, Germany \\ Correspondence: Michael C. MacCracken (mmaccrac@comcast.net)
}

Received: 27 December 2018 - Accepted: 30 January 2019 - Published: 16 April 2019

\begin{abstract}
The International Association of Meteorology and Atmospheric Sciences (IAMAS) was founded in 1919 as the Section of Meteorology of the International Union of Geodesy and Geophysics (IUGG). Significant advances over human history, particularly during the 19th century, in the gathering, communication, assembly and analysis of observations of the changing weather and in theoretical understanding of the fundamental physical relationships and processes governing atmospheric circulation had been driven by the need for improved weather and climate forecasts to support the expansion of global trade, better public warnings of extreme weather, and safer and more effective military operations. Since its foundation, in parallel and cooperation with intergovernmental development under the auspices of what is now the World Meteorological Organization (WMO), IAMAS and its 10 international commissions have provided the international organizational framework for the convening of the general and scientific assemblies and other meetings that bring together expert scientists from around the world to further advance scientific understanding and prediction of the behaviour of the atmosphere and its connections to and effects on other components of the Earth's intercoupled geophysical system.
\end{abstract}

\section{Introduction}

The successes and failures of societies around the world have been and continue to be dependent on weather and climate, especially because of their critical role in determining the availability of vital agricultural, ecological and hydrological resources. Many of the deities of the earliest civilizations represented weather- and climate-related phenomena, becoming a mechanism for organizing, explaining and passing along relationships and linkages that had been gained from prolonged observation of the timing and variability of seasons, monsoons and other phenomena to future generations. Significant departures from the expected patterns were often memorialized as conflicts between conflicting deities with such fidelity that many of the events have since been identified in paleoclimatic records.
In Greece in the fourth century BCE, Aristotle ${ }^{1}$ and Theophrastus prepared treatises describing the collective wisdom of their time, hypothesizing that various interactions among the four bodies of fire, air, water and earth provided explanations for the observed weather and climate. About 50 BCE, Andronikos Cyrrhestes constructed a $12 \mathrm{~m}$ high, octagonal horologium (known now as the Tower of Wind), which is viewed as the first meteorological observatory, serving as a sundial, water clock, compass and weather vane, with stone carvings representing each of the eight directions from which Athens' winds came over the course of the year. For many centuries, expectations regarding atmospheric phenomena were based almost solely on relationships involving Sun angle and the changing positions of constellations. Speculations were mainly qualitative with little capability of linking together what was happening in different locations

\footnotetext{
${ }^{1}$ Aristotle's treatises described what was known about meteorology, a term of Greek origin meaning atmospheric disturbances.
} 
through understanding of the intercoupled nature of the atmosphere, oceans and cryosphere.

As exploration and travel expanded, assembly and comparison of information from different regions led to observations of prevailing wind regimes and ocean currents and correlations of phenomena across regions and with geophysical events such as volcanic eruptions. Making progress, however, required both (1) instruments that could quantify observations for analysis and display as maps and (2) advances in understanding of atmospheric physics and chemistry that would eventually provide a more rigorous basis for analysis and forecasting. Advances in both areas were spurred by increasing demands for better understanding of the range of meteorological conditions that could affect public safety, military planning and actions, and expansion of trade and the global economy.

The second and third sections of this paper highlight a number of early advances with relevance to the atmospheric sciences and the gradual awareness about the need for increasing international cooperation to accelerate progress in understanding of atmospheric behaviour and for forecasting. These advances provided essential groundwork that enabled the foundation of the forerunner of today's International Association of Meteorology and Atmospheric Sciences (IAMAS) after the severe historical incision of World War I. The fourth and fifth sections describe the formative years of IAMAS following World War I and then key developments of the association since that time. Tabulated biographical information about the 35 individuals who have served as the president and/or secretary-general is also included to provide a sense of the broad spectrum of interests of those in the international scientific community that have contributed to the development of IAMAS. The sixth section provides a summary of the establishment, primary focus and key scientists that played roles in the formation and development of the 10 international commissions that form the backbone of IAMAS. The final section then contains a few concluding remarks.

\section{The early development of instruments and assembly of observations}

The quest for useful observations was significantly advanced in the 1600s when Italian polymath Galileo Galilei invented the thermometer, Italian physicist Evangelista Torricelli invented the barometer and Dutch physicist Christiaan Huygens invented the pendulum clock. During the 18th century, French nobleman Antoine-Laurent de Lavoisier, in addition to organizing understanding of chemistry by establishing the periodic table, was instrumental in identifying that the atmosphere contained, among other components, both oxygen and water vapour, the latter becoming an especially important variable to observe.
By the early 1800s, international trade led to sufficient observations being taken that initial climatological maps could start to be prepared, giving indications of typical conditions by latitude and longitude. It was not until the second half of the 19th century, however, that there were sufficient data and insights to allow preparation of synoptic maps showing such features as cyclonic and anti-cyclonic circulations and indications of their movement in time and changes in intensity. As information was accumulated, climatologies were developed to provide information for improving the routing and safety of the rapidly increasing number of sailing ships. The increasing utility of observations led directors of national meteorological services to agree in the late 19th century to standardize measurement techniques.

Assembly of information was further advanced in 1837 by American Samuel Morse's invention of the telegraph, which soon led to communication lines for rapidly transmitting and receiving observations around the world. The first reliable cable across the Atlantic Ocean began service in 1866, with further installations helping to reduce the time for assembling observations from days and weeks to hours and, starting with the first transatlantic radio communication in 1901, to minutes.

An important limitation to advancing understanding, however, was that virtually all of the regular observations were of conditions at the surface, the few exceptions including cloud type, height and cover (changes of which became an important basis for early weather forecasting); atmospheric scattering (leading to the empirical forecasting adage: "Red sky at night, sailors' delight. Red sky at morning, sailors take warning"; cf. Library of Congress, https://www.loc.gov/rr/ scitech/mysteries/weather-sailor.html, last accessed 25 January 2019); sunspot number (as a proxy for changes in solar radiation); and, beginning at a very limited number of locations in the late 19th century, observations of winds aloft using pilot balloons.

Driven by their desire to better understand the weather and climate in the adjacent North Atlantic, Norwegian meteorologist Vilhelm Bjerknes and oceanographer Bjørn HellandHansen each established institutes at the University of Bergen in 1917 that were particularly important in advancing understanding of atmospheric fronts, air-sea interactions, and other features that proved essential for forecasting system behaviour over ensuing days. During World War I, aircraft observations aloft started to become available, setting the stage for significant improvement in weather forecasts.

\section{The early development of scientific understanding}

In parallel with the development of observations leading up to the 20th century, advances were made in understanding the physics and chemistry of the atmosphere. The perfect law of gases (also known as Boyle's law after Anglo-Irishman Robert Boyle) and recognition of the three laws of motion 
put forth by England's Sir Isaac Newton in the late 17th and early 18th centuries provided the foundation for developing an understanding of global atmospheric circulation patterns. In 1735 George Hadley, an amateur English meteorologist, published a paper expanding upon English astronomer Edmond Halley's earlier explanation for the trade winds. Hadley's explanation was based primarily on consideration of the buoyancy of hot air and the Earth's rotation. The resulting circulation he derived featured a single cell extending from the Equator to high latitudes. American William Ferrel reworked the analysis in the 19th century, conserving angular rather than linear momentum, and proposed the three-cell structure recognized today, which has the Ferrel cell located between the low-latitude Hadley cell and the high-latitude Arctic circulation.

In 1824, French scientist Joseph Fourier first published an explanation for the near stability of the Earth's temperature, indicating that downward emission of infrared radiation from the atmosphere played a critical role (Fourier, 1824, 1827). The fundamental laws for thermodynamics were also formulated during the period, with many of the insights coming as a result of seeking to understand the behaviour of gases, particularly those in the atmosphere. In particular, experiments by English physicist (and brewer) James Joule and theoretical work by German physicist Rudolf Clausius established the relationship between work and heat and, with later involvement of William Thomson (later Lord Kelvin), led to the development of the law of conservation of energy as the first law of thermodynamics. Clausius was also responsible for contributing to development of the second law of thermodynamics, which posited that entropy always increases (sometimes stated as heat flows from hot to cold) and deduced what became the Clausius-Clapeyron relationship that, in the meteorological field, determines the saturation water vapour mixing ratio at various temperatures. Adding insights from experimental studies he began in the 1850s, Irish physicist John Tyndall presented proof that water vapour and carbon dioxide $\left(\mathrm{CO}_{2}\right)$ were the most important atmospheric gases contributing to what is now called the "greenhouse effect", providing a strong intellectual framework for understanding the global energy balance and the thermodynamic effects of many atmospheric processes (Tyndall, 1861).

During the same period, Scottish geologist Charles Lyell, building on the reasoning of fellow countryman James Hutton, argued that the Earth's features were a result of slow processes acting over long periods of time (uniformitarianism), rather than being mainly responses to short-term, catastrophic changes, thus rejecting notions derived from biblical genealogies that the Earth's age was only several thousand years. In books first published in the early 1830s, Lyell $(1830,1832,1833)$ went on to define and distinguish geolog-

\footnotetext{
${ }^{2}$ The term "greenhouse" has become widely used even though the actual physics keeping greenhouses warm is a result of limiting the escape of water vapour from the glass-enclosed structure.
}

ical strata (and the climatic conditions that must have been prevailing), clarifying the differences among earlier geological eras (i.e. Palaeozoic, Mesozoic and Cenozoic) and periods (e.g. dividing the Tertiary into the Pliocene, Miocene and Eocene).

Lyell's contributions over the next few decades also contributed critical information underpinning the scientific studies of England's Charles Darwin, setting atmospheric (and geophysical) scientists on a quest to document and explain changes in climate in terms of their causes. The proposal by Swedish scientist Svante Arrhenius in 1896 that changes in the atmosphere's $\mathrm{CO}_{2}$ concentration could help explain Earth's climatic history led directly to his prediction that the future climate would become warmer as a result of ongoing fossil-fuel emissions (Arrhenius, 1896). Through laborious calculations, he became the first scientist to calculate the sensitivity (i.e. responsiveness) of the climate to a doubling of the $\mathrm{CO}_{2}$ concentration, arriving at a value only slightly higher than today's central estimate. That it took over half a century for his hypothesis to be accepted was the result of two key criticisms: (1) the large carbon-holding capacity of the oceans would limit the potential rise in the atmospheric $\mathrm{CO}_{2}$ concentration (a criticism not convincingly refuted until the ocean tracer studies by American oceanographer Roger Revelle and Austro-American chemist Hans Suess in the 1950s; Revelle and Seuss, 1957) and (2) $\mathrm{CO}_{2} \mathrm{ab}-$ sorption in the atmosphere was already saturated (a criticism not convincingly refuted until the one-dimensional radiativeconvective model simulations of Japanese-American meteorologist Syukuro Manabe and American meteorologist Richard Wetherald in the 1960s showed the importance of the change in altitude at which saturation occurred; Manabe and Wetherald, 1967).

With quantitative understanding developing, British mathematician (and later meteorologist) Lewis Fry Richardson made the first attempt to actually calculate the evolution of the weather over one $6 \mathrm{~h}$ time step by quantitatively representing each of the many processes thought to alter atmospheric temperature, water vapour, pressure and winds (Richardson, 1922). Gathering all the available data for 20 May 1910 for a region in central Europe, he spent idle time while serving as an ambulance driver during World War I undertaking the extensive calculations by hand. While the forecast was unsuccessful for various reasons, the stage was set for developing numerical forecasting capabilities over ensuing decades.

\section{The start of IAMAS: formation in 1919 and topics at the 1922 assembly}

Organized international cooperation in meteorology goes back to the mid-19th century, with the first international conference convening in Brussels in 1853 (Ismail-Zadeh, 2016). Naval representatives from 10 nations (eight western Euro- 


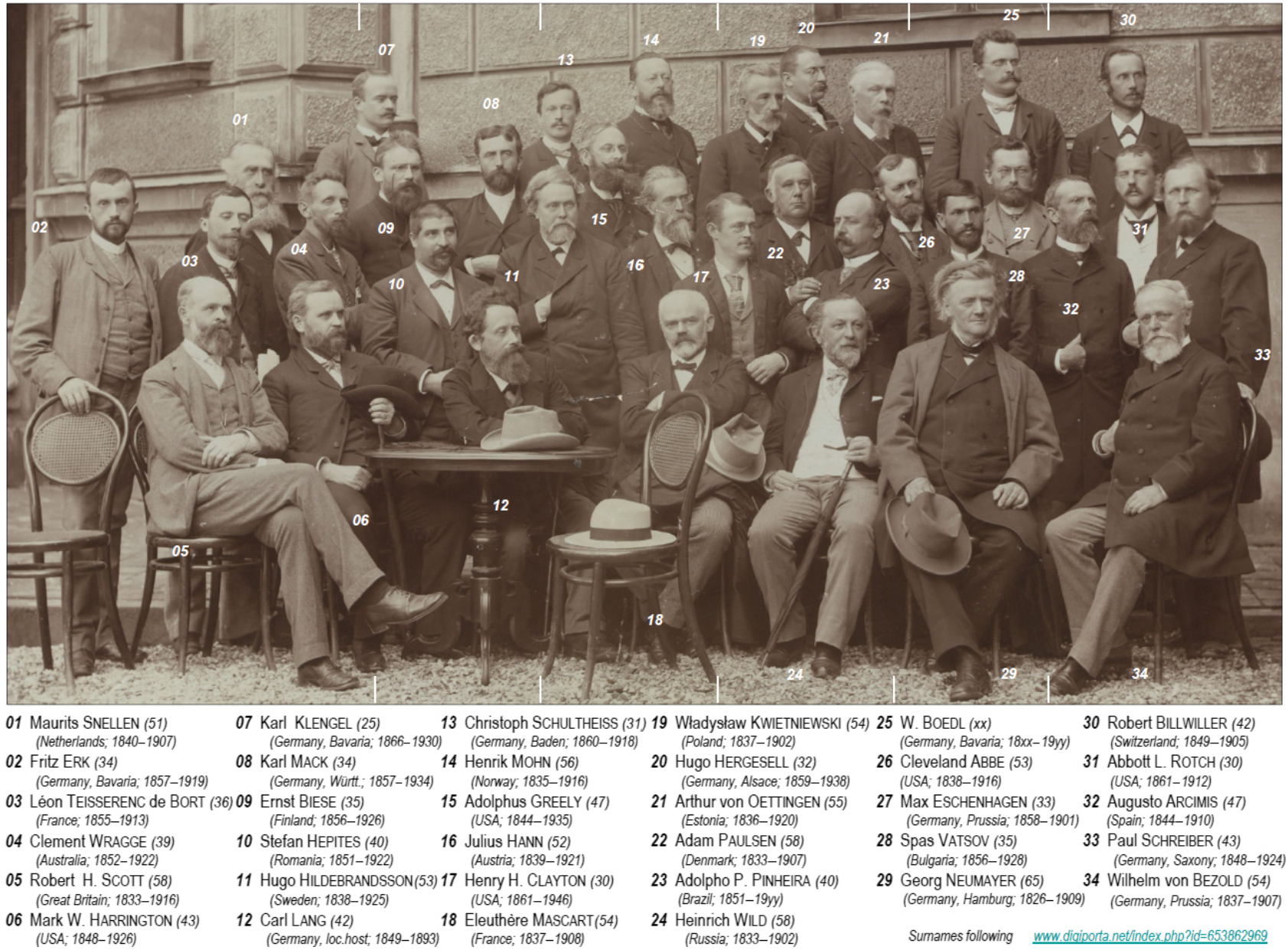

Figure 1. Participants at the International Conference of Directors of Meteorological Services, in Munich, Bavaria, Germany, 26 August2 September 1891, 28 years prior to the formation of the Section of Meteorology. Numbering is in six columns, from left to right, with the following information for each person: number, first name, surname (age at conference, representative for country or state, and lifespan). The surnames follow the handwritten note attached to the copy kept at Deutsches Museum, Digitales Porträtarchiv, Munich, Germany (cf. website http://www.digiporta.net; last access: 25 January 2019). The high-resolution scan was provided by the National Meteorological Library and Archive in Exeter, UK.

pean nations plus the USA and Russia) focused their attention on the need to improve and expand observations for weather forecasting. Their efforts eventually led to the first International Meteorological Conference in Vienna in 1873 and the formation of the International Meteorological Organization (IMO) in 1879 (and, much later, inspired the formation of the World Meteorological Organization (WMO) in 1950). The IMO was led by an International Meteorological Committee composed of the directors of the meteorological services of the member nations.

An early example of such international cooperation is documented in the group photograph taken during the summer of 1891 at the International Conference of Directors of Meteorological Services held in Munich, Germany (Fig. 1). Among the 34 attendees from more than a dozen nations on three continents were Georg Neumayer (pioneer of Southern
Hemisphere meteorology) and Wilhelm von Bezold (thermodynamicist who defined potential temperature) from Germany, Cleveland Abbe (early proponent of dynamical meteorology) from the USA, Julius Hann (global-scale collector of vast climatological datasets) from Austria, and Léon Teiserrenc de Bort (specialist in vertical soundings and co-discoverer of the stratosphere a decade later) from France. Although most participants represented fledging meteorological services, they met as experts in a personal, nongovernmental capacity and set out to distribute tasks among technical commissions (Davies, 1990, p. 4), as is still done by both IAMAS and WMO. The International Commission on Radiation and Insolation formed in 1896 (Bolle, 2008) and the International Commission for the Scientific Investigation of the Upper Air were two of the very early commissions. 


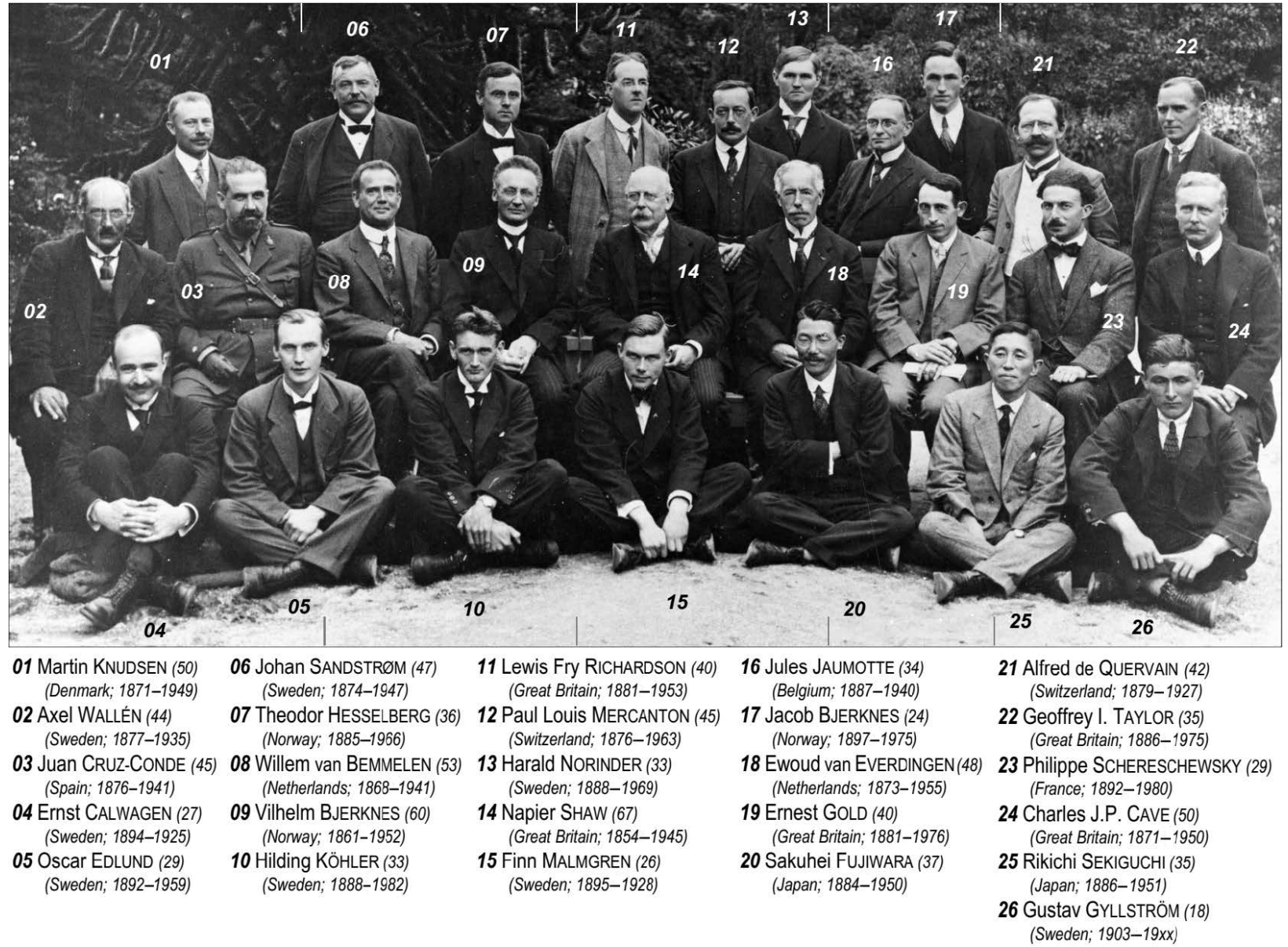

Figure 2. Participants at the eighth meeting of the International Commission for the Scientific Investigation of the Upper Air on 25 July 1921 , in Bergen, Norway, 2 years after the formation of the Section of Meteorology. Numbering is in five columns, from left to right, with the following information for each person: number, first name, surname (age at conference, country of work - not necessarily nationality - and lifespan). The high-resolution scan was provided by the University Library in Bergen, Norway.

As World War I was coming to a close in late 1918, leading scientists in the allied nations began advancing plans for peaceful cooperation and scientific advancement under the League of Nations. That international cooperation in the development and application of meteorological observations and forecasting had been going on for a half-century provided a strong basis for the effort to expand such cooperation across a broader spectrum of the geophysical sciences. Led by representatives of the national academies of science of the various nations ${ }^{3}$, discussions and planning meetings led, within a year, to the formation of the international scientific structure that has persisted for virtually all of the period since (Shaw, 1923). The International Research Council (IRC) was

\footnotetext{
${ }^{3}$ That leaders of meteorological sciences in the national academies were also often leaders in their government's activities was relatively unique across the geophysical sciences, showing in a very real sense how scientific advances in atmospheric sciences could rapidly be applied by governments for the benefit and safety of their citizens and economic and governmental activities.
}

formed first and held its first plenary meeting in Brussels in late July 1919 (Schuster, 1921; the IRC was the predecessor of the International Council of Scientific Unions - ICSU, recently merged with the International Social Science Council to form the International Science Council). The International Union for Geodesy and Geophysics (IUGG) was established within the IRC. It was composed initially of six sections, one being the Meteorology Section (Bauer, 1919a).

At the Brussels plenary, Sir Napier Shaw of UK's Royal Society was appointed President of the Bureau for the Section de Météorologie, hereafter referred to as the Meteorology Section. Shaw had emphasized greater reliance on science (as opposed to empirical analysis) in his leadership of the British Meteorological Office during World War I (including by employing Lewis Richardson). Charles Alfred Angot, earlier Directeur du Bureau Central Météorologique de France, was selected as vice president, and Charles F. Marvin, then chief of the US Weather Bureau, was selected as secretary (Bauer, 1919b). While each 
had been or was a leader of their government's meteorological service, the Meteorology Section was a creation of the national academies of science of the participating countries rather than of government meteorological organizations. The focus of the non-governmental effort was intended to be on the scientific questions arising in the study of meteorology and geophysics in contrast to the more empirical and observational emphasis of the governmental efforts that were focused mainly on operational forecasting and ensuring public safety. That these efforts had been ongoing together for so long provided a strong basis for their ongoing cooperation and connection.

Each nation was called upon to have a national committee for IUGG, providing a member to serve as a representative to each of its sections; this requirement proved instrumental in spurring organization and cooperation among each of the disciplines in the member countries. Members of the atmospheric science community were active participants in the organizational efforts (Shaw, 1923). For example, climatologist Hubert Lamb was included along with those affiliated with the UK Meteorological Service as UK's representatives; France formed an IUGG national committee, of which 49 of its 124 members were affiliated with the Section of Meteorology; and in the USA, formation of the national committee spurred organization in 1919 of both the American Meteorological Society and what later became the American Geophysical Union (Wood, 1920).

The photograph of participants at the eighth meeting of the International Commission for the Scientific Investigation of the Upper Air (Fig. 2) held in Bergen, Norway, in 1921 shows many of those who were engaged with the early development of the Section of Meteorology, including Sir Napier Shaw (the section's founding president), Vilhelm Bjerknes (who served as president from 1935-1936) and his son Jacob Bjerknes (who served as secretary-general from 1936 to 1948 and president from 1951-1954). Right from the beginning, the enthusiasm for international cooperation on a voluntary basis appears to have been a natural and steady ingredient of most gatherings of IUGG's sections and their successors (cf. Gold, 1921; Volkert, 2017). A brief but vivid eyewitness account was provided some 55 years after the meeting in Bergen by Schereschewsky (1977), including succinct appraisals of later achievements by some of the participants.

By providing their sections with an annual allocation from the collective dues paid by the national academy of each of the 20 initial member nations, IUGG provided resources for their Sections to actually organize research activities. This was in contrast to the IMO, which did not at that time provide funds to promote cooperative activities. That this effort to promote international research was seen as a particularly important endeavour by the participating nations is suggested by the fact that the US Congress explicitly endorsed the effort and specifically allocated funding for IUGG membership in its annual budget actions over IUGG's first several years.
The first major action of the Meteorology Section's Bureau was to call for proposals from the national committees for research topics and questions to be placed on the agenda for the first IUGG general assembly to be held in Rome in 1922. In his report to the Royal Meteorological Society, Shaw (1923) explained 11 topical areas (or "gaps of knowledge") that had been submitted by the national committees of Great Britain, France and Italy (collected in Table 1). Many of the suggested topics continued to be of such interest that they later became the basis for formation of many of the commissions that now exist.

Nine nations are reported to have sent delegates to the first meeting of the Meteorology Section at the Rome general assembly: Australia, Belgium, France, Great Britain, Italy (in large numbers), Portugal, Spain, Sweden and the USA. Resolutions approved were related to the following subjects (Kimball, 1922), which were closely linked to the abovementioned topical areas:

1. allocating much of the Section's funding to initiate an enhanced network of balloon sondes to explore the upper atmosphere;

2. allocating much of the remaining resources for study of the stratosphere through expansion of the pilot-balloon network, especially in the desert regions and around the Equator;

3. developing a cooperative field and theoretical programme on convection;

4. preparing a report on the effects of radiation on atmospheric circulation, including by taking measurements at different mountain observatories around the world (this resolution led to establishment of the Commission of Solar Radiation in 1924 with Herbert H. Kimball from the US Weather Bureau as president);

5. purchasing and distributing a number of instruments to measure haze;

6. developing the capability to measure hydrogen at different locations and altitudes;

7. surveying the methods of doing weather forecasting around the world;

8. collaborating with the Commission on Clouds formed by the International Meteorological Committee (IMC);

9. promoting application of modern statistical methods to calculate normals;

10. meeting with the International Meteorological Committee to discuss potential overlaps and cooperation. 
Table 1. Numbered topics ("gaps in our knowledge") outside of the routine investigations of meteorological services, suggested by three National Committees of IAM for discussion at the general assembly of 1922 in Rome (Shaw, 1923).

\begin{tabular}{lll}
\hline Country & no. & Topic \\
\hline \multirow{4}{*}{ Great Britain } & 02 & $\begin{array}{l}\text { Lack of observations of temperature and wind velocity in the upper air over the sea and over deserts or inhos- } \\
\text { pitable regions }\end{array}$ \\
& 03 & What are immediate and longer-term effects of active convection on the surrounding atmosphere? \\
& 04 & Role of radiation in the sequence of weather and for the large-scale vertical circulation \\
& 05 & Impairment of visibility, measurements of hygroscopic aerosols to address atmospheric pollution \\
& 06 & Composition of the atmosphere above 100 km. Is hydrogen main constituent at such heights? \\
& 07 & Different sorts of thunderstorms and, more generally, electrical phenomena \\
France & 08 & Transparency of the atmosphere and its optical phenomena \\
& 09 & Different sorts of clouds \\
& 10 & Forecasting weather, in particular the method of tendencies (isallobars) \\
\hline Italy & 11 & Necessity for presenting normals of meteorological data according to modern statistical methods \\
\hline
\end{tabular}

\section{Growing international cooperation in atmospheric sciences}

Following the general assembly in Rome in 1922, the Meteorology Section met every 3 years (except for the years during World War II) as part of the triennial general assemblies of IUGG until the IUGG decision in 1967 to meet every 4 years (see Ismail-Zadeh and Joselyn, 2019). At the fifth IUGG general assembly in Lisbon in 1933, it was decided to refer to the IUGG Sections as Associations, and so the Meteorology Section was renamed the International Association of Meteorology (IAM); it was then renamed the International Association of Meteorology and Atmospheric Physics (IAMAP) at the 11th IUGG general assembly in Toronto in 1957. Nearly 4 decades later, recognizing the very important role of other traditional scientific disciplines in atmospheric studies, the name was officially changed to the International Association of Meteorology and Atmospheric Sciences (IAMAS) at the 21st general assembly held in Boulder in 1995. Hereafter in this chapter, the association's current name will be used.

Since its beginning, IAMAS has been led by a president, with administrative and organizational activities directed by a secretary-general nominated by the national committees that are members of IUGG. New officers are elected at each of the IUGG general assemblies to serve from the conclusion of that gathering through the next general assembly. Succinct biographical information and portraits are provided for all 23 presidents in Table 2 and Fig. 3 and for all 12 secretariesgeneral in Table 3 and Fig. 4. All of the officers have been trained as scientists, but they come from a broad range of disciplines, including geography, meteorology, physics, astronomy and mathematics. Up to the 1970s, many of the officers were employees of the national meteorological services, while since then their primary employment has been by universities and research laboratories.
From the time of its formation, IAMAS has been cooperating with the international meteorological organizations organized by the world's national governments. With the formation of the United Nations, IMO's role was taken over by the World Meteorological Organization (WMO) in 1950 (Davies, 1990). A formal agreement between IUGG and WMO was worked out in 1953 that has governed their respective roles since that time, with WMO taking the leading role in organizing meetings of the international meteorological service organizations and IUGG (through IAMAS) organizing meetings aimed at advancing the science of meteorology. To ensure ongoing cooperation, IUGG has, since signing the agreement, appointed a formal liaison with WMO, often a scientist drawn from IAMAS.

A major undertaking of IUGG and its associations in cooperation with other international unions and entities was sponsorship and organization of the International Geophysical Year (IGY) in 1957-1958. Along with later satellitebased data, data from the expanded observation network established during IGY has made clear that Planet Earth must be considered as an integrated whole. To ensure ongoing cooperation in observations and research, ICSU created the Scientific Committee on Oceanic Research (SCOR) in 1957 and the Scientific Committee on Antarctic Research (SCAR) in 1958 to promote interdisciplinary science on the oceans and Antarctica, respectively. Ever since then, IAMAS has had representation in these organizations, participating in their governance on behalf of IUGG.

Beginning in the 1970s, IAMAS and the other IUGG Associations began holding their own (sometimes joint) Scientific Assemblies in the years between the quadrennial IUGG general assemblies (Table 4). The first such IAMAS Scientific Assembly was convened jointly with the International Association of the Physical Sciences of the Ocean (IAPSO) in Melbourne in 1974. The assembly drew participation from nations on both sides of the "Cold War," an openness to all 
Table 2. Succinct biographical information about the 23 persons who have served as IAMAS presidents; photographs are presented in Fig. 3. Under academic training, the subject of graduation is listed (typically for a $\mathrm{PhD}$ or MSc degree).

\begin{tabular}{|c|c|c|c|c|c|}
\hline no. & First name, surname & $\begin{array}{l}\text { Country } \\
\text { (of work) }\end{array}$ & Office term & Lifespan & $\begin{array}{l}\text { Academic training; primary expertise (role at mete- } \\
\text { orological service - mets) }\end{array}$ \\
\hline 01 & W. Napier Shaw & UK & $1919-1930$ & $1854-1945$ & $\begin{array}{l}\text { Physics; atmospheric dynamics and synoptics (di- } \\
\text { rector, UK mets) }\end{array}$ \\
\hline 02 & Axel Wallén & Sweden & $1930-1935$ & $1877-1935$ & $\begin{array}{l}\text { Geography; climatology, agricultural meteorology } \\
\text { (director, Swedish mets) }\end{array}$ \\
\hline $02 \mathrm{a}$ & Vilhelm Bjerknes ${ }^{\mathrm{a}}$ & Norway & 1935-1936 & $1862-1951$ & $\begin{array}{l}\text { Physics; atmospheric dynamics and synoptics, fore- } \\
\text { casting }\end{array}$ \\
\hline 03 & Sidney Chapman & UK & $1936-1948$ & $1888-1970$ & $\begin{array}{l}\text { Mathematics; geomagnetism, kinetic theory of } \\
\text { gases }\end{array}$ \\
\hline 04 & Jacob Bjerknes & USA & $1948-1951$ & $1897-1975$ & Physics; forecasting, dynamics, oceanography \\
\hline 05 & Kalpathi Ramanathan & India & 1951-1954 & $1893-1984$ & $\begin{array}{l}\text { Physics; geophysical observations, aerology (direc- } \\
\text { tor, Indian mets) }\end{array}$ \\
\hline 06 & Carl-Gustaf Rossby & Sweden & $1954-1957$ & $1898-1957$ & $\begin{array}{l}\text { Mathematics; forecasting, dynamics, atmospheric } \\
\text { chemistry }\end{array}$ \\
\hline 07 & Jacques van Mieghem & Belgium & $1957-1960$ & $1905-1980$ & $\begin{array}{l}\text { Mathematics; geomagnetism, aerology (director, } \\
\text { Belgian mets) }\end{array}$ \\
\hline 08 & Horace R. Byers & USA & $1960-1963$ & $1906-1998$ & $\begin{array}{l}\text { Geography; synoptic and aviation meteorology } \\
\text { (scientist, US mets) }\end{array}$ \\
\hline 09 & Alexander M. Obukhov & USSR & $1963-1967$ & $1918-1989$ & Physics; theory of atmospheric turbulence \\
\hline 10 & Reginald C. Sutcliffe & UK & 1967-1971 & 1904-1991 & $\begin{array}{l}\text { Mathematics; forecasting, dynamics (research di- } \\
\text { rector, UK mets) }\end{array}$ \\
\hline 11 & Sigmund Fritz & USA & $1971-1975$ & $1914-2015$ & Mathematics; solar radiation, satellite meteorology \\
\hline 12 & Christian Junge & FR Germany & $1975-1979$ & 1912-1996 & Meteorology; atmospheric chemistry, aerology \\
\hline 13 & Warren L. Godson & Canada & $1979-1983$ & 1920-2001 & $\begin{array}{l}\text { Chemistry; forecasting, aerology (research director, } \\
\text { Canadian mets) }\end{array}$ \\
\hline 14 & Hans-Jürgen Bolle & Austria & 1983-1987 & 1929-2013 & Physics; radiation, satellite meteorology \\
\hline 15 & G. Brian Tucker & Australia & 1987-1991 & 1930-2010 & $\begin{array}{l}\text { Mathematics; global circulations, atmospheric } \\
\text { chemistry (scientist, Austral. mets) }\end{array}$ \\
\hline 16 & Brian J. Hoskins & UK & $1991-1995$ & $1945-$ & Mathematics; dynamics of weather and climate \\
\hline 17 & Robert A. Duce & USA & 1995-1999 & $1935-$ & Chemistry; atmospheric and marine chemistry \\
\hline 18 & Huw C. Davies & Switzerland & 1999-2003 & $1944-$ & Mathematics; atmospheric dynamics, modelling \\
\hline 19 & Michael C. MacCracken & USA & 2003-2007 & $1942-$ & $\begin{array}{l}\text { Applied science; modelling, climate change, paleo- } \\
\text { climate }\end{array}$ \\
\hline 20 & Guoxiong Wu & China & $2007-2011$ & $1943-$ & $\begin{array}{l}\text { Meteorology; forecasting, dynamics, mountain ef- } \\
\text { fects }\end{array}$ \\
\hline 21 & Athéna Coustenis & France & 2011-2015 & $1961-$ & $\begin{array}{l}\text { Astronomy; planetary atmospheres, comparative cli- } \\
\text { matology }\end{array}$ \\
\hline 22 & John Turner & UK & 2015-2019 & $1953-$ & $\begin{array}{l}\text { Meteorology; forecasting, polar meteorology, cli- } \\
\text { mate change }\end{array}$ \\
\hline
\end{tabular}

${ }^{a}$ Vilhelm Bjerknes was vice president of IAM when president Axel Wallén died in 1935; Bjerknes then acted as president during the meteorology sessions at the IUGG general assembly held in 1936 in Edinburgh. 


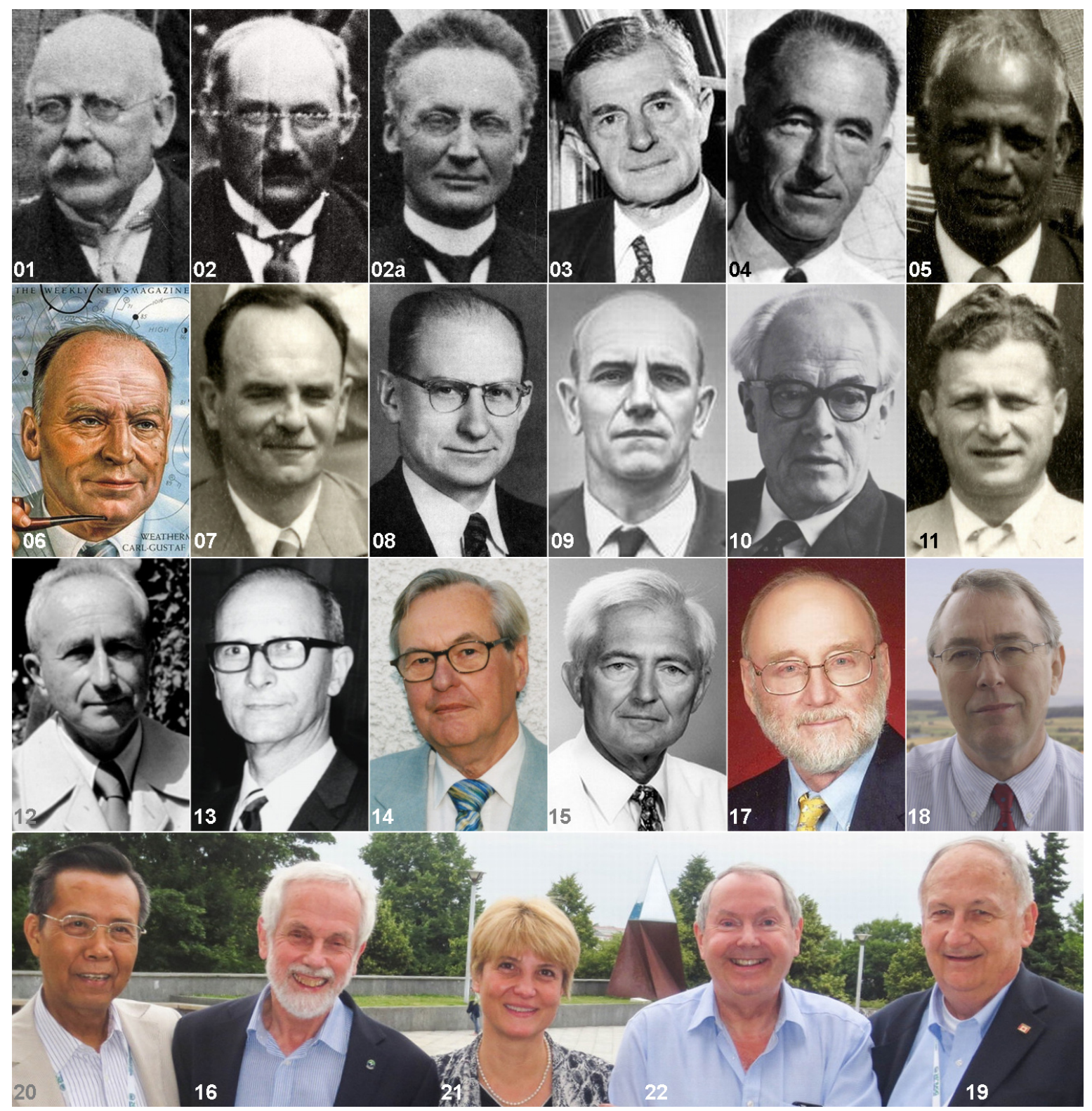

Figure 3. Collection of portraits of the 23 IAMAS presidents serving from 1919 to 2019: (01) Napier Shaw, (02) Axel Wallén, (02a) Vilhelm Bjerknes (acting president after Wallén's death in 1935), (03) Sidney Chapman, (04) Jacob Bjerknes, (05) Kalpathi Ramanathan, (06) Carl-Gustaf Rossby, (07) Jacques van Miehgem, (08) Horace Byers, (09) Alexander Obukhov, (10) Reginald Sutcliffe, (11) Sigmund Fritz, (12) Christian Junge, (13) Warren Godson, (14) Hans-Jürgen Bolle, (15) Brian Tucker, (16) Brian Hoskins, (17) Robert Duce, (18) Huw Davies, (19) Michael MacCracken, (20) Guoxiong Wu, (21) Athéna Coustenis and (22) John Turner. See Table 2 for detailed information. Photo credits: the bottom row depicts five presidents (no. 16, 19-22) together at IUGG-2015 in Prague (positions not in chronological order), ( Maggie Turner; for 06, (C) Time Magazine, vol. 68, no. 25, 17 December 1956; no. 01, 02 and 02a, cuttings from Fig. 2; no. 05, 07 and 11, cuttings from group photograph of 1959 (C B. J. Harris; Ohring et al., 2009); no. 3 and 13 from Bojkov, 2012 ; and other portraits from web sources.

that IUGG and its associations now enshrine. Given the geophysical continua of the solid, liquid, and gaseous Earth, atmospheric studies under the umbrella of IAMAS benefitted significantly from the advances in observations and understanding led by a number of its sister associations, primarily involving IAGA (Mandea and Petrosky, 2019), IAPSO
(Smythe-Wright et al., 2019), IAHS (Rosbjerg and Rodda, 2019) and IACS (Allison et al., 2019).

The variable climatic conditions of the 1970s and the emerging indications that human activities were starting to influence the climate led to formation of the World Climate Research Programme (WCRP) by ICSU (IUGG's parent or- 
Table 3. Succinct biographical information about the 12 persons who have served as IAMAS secretaries-general; photographs are presented in Fig. 4. Under academic training, the subject of graduation is listed (typically for a $\mathrm{PhD}$ or MSc degree).

\begin{tabular}{|c|c|c|c|c|c|}
\hline no. & First name, surname & $\begin{array}{l}\text { Country } \\
\text { (of work) }\end{array}$ & Office term & Lifespan & $\begin{array}{l}\text { Academic training; primary expertise (role at meteo- } \\
\text { rological service - mets) }\end{array}$ \\
\hline 01 & Charles F. Marvin & USA & $1919-1922$ & $1858-1943$ & Meteorology; design of instruments (chief, US mets) \\
\hline 02 & Filippo Eredia & Italy & $1922-1927$ & $1877-1948$ & $\begin{array}{l}\text { Physics; forecasting, especially for aviation (director, } \\
\text { Italian mets) }\end{array}$ \\
\hline 03 & Philippe Wehrlé & France & $1927-1936$ & $1890-1965$ & $\begin{array}{l}\text { Engineering; synoptics, atmospheric turbulence (di- } \\
\text { rector, French mets) }\end{array}$ \\
\hline 04 & Jacob Bjerknes & Norway-USA & $1936-1948$ & $1897-1975$ & $\begin{array}{l}\text { Physics; forecasting, dynamics, oceanography (direc- } \\
\text { tor, western Norway mets) }\end{array}$ \\
\hline 05 & Jacques van Mieghem & Belgium & $1948-1954$ & $1905-1980$ & $\begin{array}{l}\text { Mathematics; geomagnetism, aerology (director, Bel- } \\
\text { gian mets) }\end{array}$ \\
\hline 06 & Reginald C. Sutcliffe & UK & 1954-1960 & 1904-1991 & $\begin{array}{l}\text { Mathematics; forecasting, dynamics (research direc- } \\
\text { tor, UK mets) }\end{array}$ \\
\hline 07 & Warren Godson & Canada & $1960-1975$ & 1920-2001 & $\begin{array}{l}\text { Chemistry; forecasting, aerology (research director, } \\
\text { Canadian mets) }\end{array}$ \\
\hline 08 & Stanley Ruttenberg & USA & $1975-1987$ & $1926-2017$ & Physics; international manager for NAS, IGY, GARP \\
\hline 09 & Michael Kuhn & Austria & 1987-1995 & $1943-$ & Atmospheric physics; radiation, aerosols, glaciology \\
\hline 10 & Roland List & Canada & $1995-2007$ & 1929-2019 & $\begin{array}{l}\text { Physics; cloud physics, weather modification (deputy } \\
\text { secretary-general, WMO) }\end{array}$ \\
\hline 11 & Hans Volkert & Germany & $2007-2015$ & $1955-$ & Meteorology; mesoscale dynamics, field campaigns \\
\hline 12 & Teruyuki Nakajima & Japan & 2015-2019 & $1950-$ & Atmospheric physics; radiation, climate \\
\hline
\end{tabular}

ganization) and WMO in 1980, with UNESCO's Intergovernmental Oceanographic Commission joining as a sponsor in 1993. The WCRP Joint Scientific Committee (JSC) was formed, drawing members from both the governmental and non-governmental scientific community. The JSC and a sister body under the International Geosphere Biosphere Programme (IGBP) organized a number of major projects, often in cooperation with IUGG and its various components (including IAMAS and its commissions), covering the Earth system from the surface to the stratosphere and the tropics to the poles as well as physical, chemical and biological processes from the hydrologic cycle to cycling of atmospheric pollutants. Over ensuing decades, IAMAS has appointed representatives to participate in both planning meetings and project activities, especially when the area of study has included the atmosphere.

\section{The backbone of IAMAS: its 10 international commissions}

The wide range of topics considered at the Rome general assembly made clear that the scope of important topics encompassed in atmospheric sciences is large. With observation and research efforts intensifying through the 20th cen- tury, the number of specialists in each of the particular areas grew, leading to IAMAS adopting an internal structure that would promote focused development and cooperation in each area while still encouraging integration across the study of meteorology and atmospheric sciences.

To accomplish this, IAMAS has, over its history, established 10 scientific commissions (see Table 5). Each commission has a particular scientific focus and its own set of officers and members. In addition to describing the scientific scope of each commission, the following paragraphs list a few of the many scientists from around the world who have been responsible for advancing understanding in each area, generally focusing on those involved in the early to mid-20th century and even before. A good number of these commissions have become so large that they convene their own scientific meetings, typically bringing together hundreds of scientists, most often in years other than those when IUGG general assemblies and IAMAS scientific assemblies are held. In addition to meetings held under IUGG and IAMAS auspices, many of the commissions also arrange to meet jointly with other IUGG associations or are involved with them in related or co-sponsored international scientific programmes. In addition, commission members often serve as representatives to or are on the leadership teams for scientific projects 


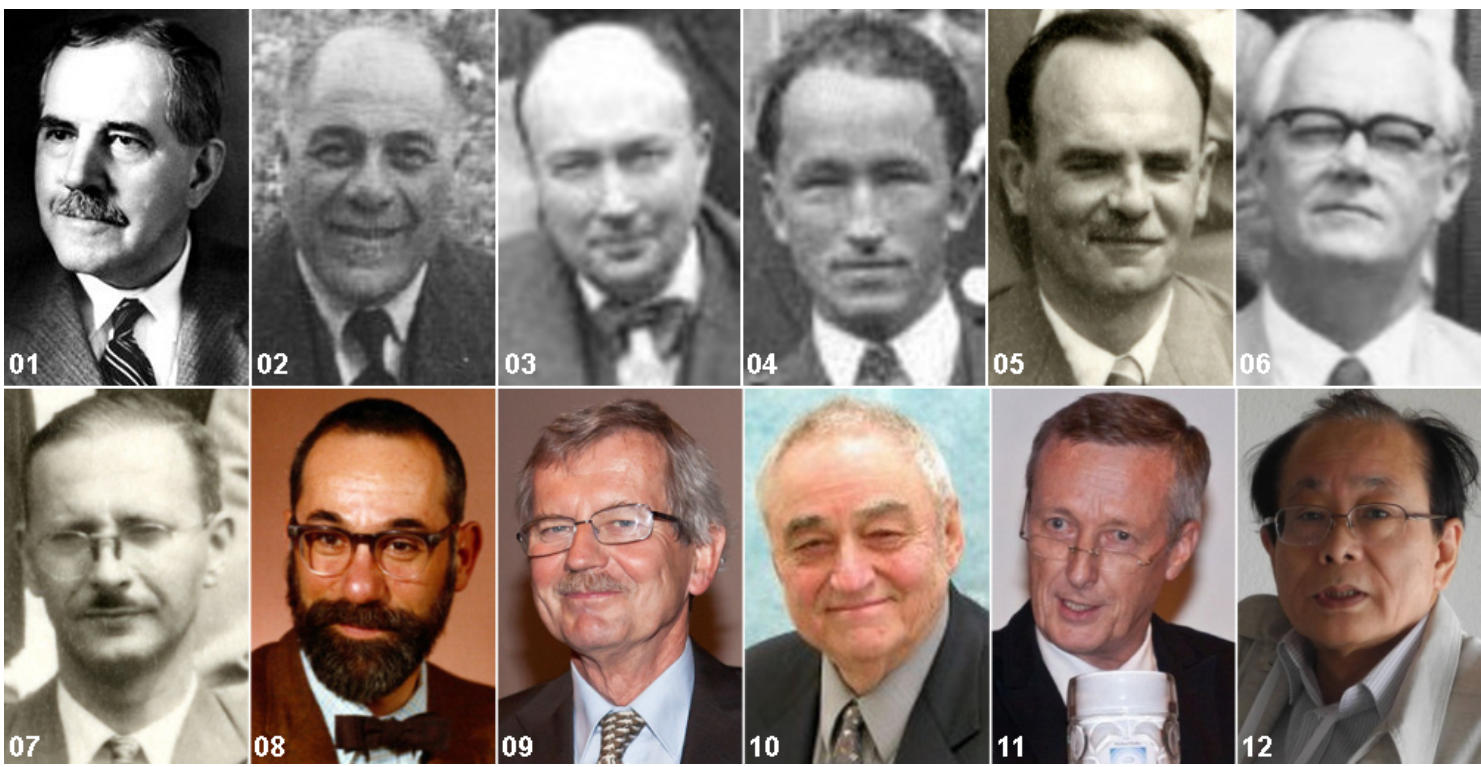

Figure 4. Collection of portraits of the 12 IAMAS secretaries-general serving from 1919 to 2019: (01) Charles Marvin, (02) Filippo Eredia, (03) Philippe Wehrlé, (04) Jacob Bjerknes, (05) Jacques van Mieghem, (06) Reginald Sutcliffe, (07) Warren Godson, (08) Stanley Ruttenberg, (09) Michael Kuhn, (10) Roland List, (11) Hans Volkert and (12) Teruyuki Nakajima. See Table 3 for detailed information. Photo credits: $\mathbf{0 3}$ and 04, cuttings from group photograph of 1936 (Bojkov, 2012; Fig. 4; (C) Oxford University); 05-07 cuttings from group photograph of 1959 (@ B. J. Harris; Ohring et al., 2009); 09 and 11 in October 2011 (ㅇ Markus Weber); 12 in June 2015 (@) Hans Volkert); and other portraits from web sources.)

sponsored by other international bodies. A comparison of the leading scientists mentioned in the commission highlights below with the names of officers listed in Tables 2 and 3 reflects the organizing notion of IUGG that its associations have officers drawn from those who can be prominent and knowledgeable spokespersons for the scientific areas encompassed by its commissions.

\subsection{International Radiation Commission}

The approval of IAMAS Commissions began in 1948 when the International Radiation Commission (IRC) was formed by merging the existing Commission of Solar Radiation with the considerably older Radiation Commission that had been chartered by IMO in 1896. A comprehensive history has been compiled by German-Austrian scientist HansJürgen Bolle (2008), while American George Ohring et al. (2009) described joint undertakings with the International Ozone Commission since a conference that was held in Oxford, UK, in 1959.

In its earliest days, the focus was on the development and accuracy of instruments and measurement techniques in order to generate better understanding of the transmission of solar radiation through both clear and cloudy conditions, particularly seeking to determine if and how the Sun's output has been changing. Complicating the determination of solar variability have been natural and humancaused atmospheric aerosols of various types. Among the leading radiation scientists during these formative years of IRC and earlier were Jules Violle and C. Alfred Angot (both France), Anders Ångström (Sweden), Jules Maurer and Walter Mörikofer (both Switzerland), Fritz Möller (Germany), Kirill Ya. Kondratyev (USSR), Giichi Yamamoto (Japan), Sir John Houghton (UK), and Herbert H. Kimball and Julius London (both USA).

Through the 20th century, there has been increasing attention devoted to the determination and calculation of infrared radiation and how the many gases in the atmosphere, especially gases being augmented by human-caused emissions, are influencing and strengthening the atmosphere's absorption and emission of infrared radiation, both upward toward space and downward toward the surface, thus strengthening the natural greenhouse effect. The understanding gained regarding the Earth's radiation and energy balance has proved essential in improving understanding of both natural variability and long-term climate change, including how past changes in solar insolation, volcanic aerosol loading, land cover change and human activities, particularly fossil-fuel combustion, have together affected the Earth's energy balance and the resulting weather and climate. With solar radiation essential for food production, ecosystem growth, and direct and indirect forms of renewable energy, among many other societal and ecosystem interactions, the scope of IRC's scientific coverage remains broad and critical. 
Table 4. General information about special IAMAP (no. 01-05) and IAMAS (no. 06-13) scientific assemblies convened between the general assemblies of IUGG, from 1974 onwards. For earlier assemblies, see the table of locations of general assemblies provided in the article on the history of IUGG (Ismail-Zadeh and Joselyn, 2019).

\begin{tabular}{lrllllrr}
\hline no. & Year & Location & Country & Continent & Joint with & Acronym & Number delegates \\
\hline 01 & 1974 & Melbourne & Australia & Australia & IAPSO & 600 \\
02 & 1977 & Seattle & USA & North America & IAGA & 950 \\
03 & 1981 & Hamburg & FR Germany & Europe & & 820 \\
04 & 1985 & Hawaii & USA & North America & IAPSO & & 450 \\
05 & 1989 & Reading & UK & Europe & IAPSO & 1020 \\
\hline 06 & 1993 & Yokohama & Japan & Asia & IAHS & 450 \\
07 & 1997 & Melbourne & Australia & Australia & IAPSO & & 1100 \\
08 & 2001 & Innsbruck & Austria & Europe & & 850 \\
09 & 2005 & Beijing & China & Asia & & 840 \\
10 & 2009 & Montreal & Canada & North America & IAPSO, IACS & MOCA-09 & 450 \\
11 & 2013 & Davos & Switzerland & Europe & IACS & DACA-13 & 950 \\
12 & 2017 & Cape Town & South Africa & Africa & IAGA, IAPSO & & 1000 \\
13 & 2021 & Busan & South Korea & Asia & IAPSO, IACS & MOCA-21 (being planned) \\
\hline
\end{tabular}

Table 5. International commissions (IC) within the International Association of Meteorology and Atmospheric Sciences, listed by year of formation.

\begin{tabular}{|c|c|c|c|}
\hline Year & Acronym & Name & Link to website (last access for all URLs: 25 January 2019) \\
\hline 1948 & IRC & International Radiation Commission & http://www.irc-iamas.org \\
\hline 1948 & $\mathrm{IO}_{3} \mathrm{C}$ & International Ozone Commission & http://www.io3c.org \\
\hline 1953 & $\mathrm{ICCP}$ & IC on Cloud and Precipitation & http://www.iccp-iamas.org \\
\hline 1966 & CNAA & Committee on Nucleation and Atmospheric Aerosols & http://www.icnaa.org \\
\hline 1957 & ICACGP & IC on Atmospheric Chemistry and Global Pollution & http://www.icacgp.org \\
\hline 1963 & ICPM & IC on Polar Meteorology & http://www.icpm-iamas.aq \\
\hline 1967 & ICDM & IC on Dynamical Meteorology & http://icdm.atm.ucdavis.edu/ICDM.html \\
\hline 1977 & ICCL & IC on Climate & http://www.iccl-iamas.net \\
\hline 1977 & ICPAE & IC on Planetary Atmospheres and their Evolution & http://icpae.iaps.inaf.it \\
\hline 1979 & ICMA & IC on the Middle Atmosphere & http://icma.iaa.es \\
\hline 1989 & ICAE & IC on Atmospheric Electricity & http://icae.jp \\
\hline
\end{tabular}

\subsection{International Ozone Commission}

Noticing the sharp cut-off in the radiation spectrum at UV wavelengths, Marie Alfred Cornu (France) was the first to suggest in 1879 that this was due to atmospheric absorption (Cornu, 1879). A year later, Sir Walter Noel Hartley (UK) suggested that absorption by ozone was the cause; the absorption band is now named after him (Hartley, 1880). Together they recognized that the ozone must be present in the upper atmosphere, being formed there by the missing UV radiation. While early observations showed variations through the year, it took until the invention of the spectrometer in 1924 by British physicist and meteorologist Gordon Dobson for there to be an instrument that could be used to make reliable and comparable measurements around the world.

The first international Conference on Ozone was held in Paris in 1929 and the second in Oxford in 1936 (Meetham, 1936). An expression of interest in becoming affiliated with the Section of Meteorology led initially to formation of a Committee on Ozone by the Commission on Solar Radia- tion; it was this committee that was recognized as the International Ozone Commission (IOC) in 1948 (Bojkov, 2012). Leading scientists in this early progression included Gordon Dobson (UK), Charles Fabry (France), Marcel Nicolet (Belgium), Sydney Chapman and Sir David R. Bates (both UK), Anna Mani (India), and F. W. Paul Götz (Switzerland), with Dobson becoming the IOC's first president.

The availability of a strong understanding of stratospheric ozone chemistry became critical in the 1970s as threats to its vital role emerged as a result of proposals for establishing a fleet of supersonic passenger aircraft and then as a result of the rising emissions of chlorofluorocarbons (CFCs) and other halocarbons. Observations and analyses of stratospheric ozone depletion and then the Southern Hemisphere's springtime "ozone hole" prompted international adoption of the Montreal Protocol and subsequent amendments. Since then, there has been the start of a recovery (not to mention that cutting CFC emissions has also been an important contribution to cutting greenhouse gas emissions). Scientific advances in this field were internationally recognized in 1995 
with the award of the Nobel Prize in chemistry given to Paul Crutzen (the Netherlands and Germany), Mario Molina (Mexico and USA) and F. Sherwood Rowland (USA).

\subsection{International Commission on Clouds and Precipitation}

The International Commission on Clouds and Precipitation (ICCP) was the third IAMAS Commission to be established, being approved in 1953 and holding its first official meeting in 1954. Clouds and precipitation have been of interest from earliest times and have been regularly recorded by weather stations since the second half of the 19th century. To help improve consistency in observations, the IMO created a Clouds Commission that issued the first edition of the Cloud Atlas in 1896 (International Meteorological Committee, 1896); it has been regularly updated since. Clouds have been of particular importance because of their value in understanding atmospheric circulation, particularly relating to atmospheric moisture and precipitation and their role in affecting the energy and water balances. The ICCP created a Committee on Nucleation and Atmospheric Aerosols in 1966 to bring even more focused attention to the science of cloud microphysics, tropospheric and stratospheric aerosols, and aerosol-climate interactions.

Leading scientists in the early development of understanding of clouds, precipitation and convection included Tor Bergeron (Sweden), Horace Byers and Joanne Simpson (both USA), Tetoya "Ted" Fujita (Japan and USA), Sir John Mason (UK), and Hans Pruppacher (Germany). With fresh water being an absolutely vital resource for the world's growing population, developing the capabilities for forecasting precipitation and changes in its distribution and intensity over time will be essential for sustaining the world's peoples and communities.

\subsection{International Commission on Atmospheric Chemistry and Global Pollution}

The fourth commission created by IAMAS was the International Commission on Atmospheric Chemistry and Radioactivity, which was approved in 1957 and was most focused on urban pollution and fallout from nuclear testing. It was renamed the International Commission on Atmospheric Chemistry and Global Pollution (ICACGP, later iCACGP) in 1971, recognizing that the chemistry and composition of the atmosphere was really an issue that reached from urban to global scales and that, with the phasing out of nuclear testing in the mid-1960s, surface deposition of air pollutants, especially the sulphate compounds that caused acid precipitation, had replaced radioactivity as a more immediate issue of societal and ecological concern.

iCACGP's members played a leading role in establishing the International Geosphere Biosphere Programme (IGBP), which coordinated studies in the area from 1987 to 2015, and initiating and sponsoring a number of important international research projects, including IGAC (International Global Atmospheric Chemistry), SOLAS (Surface OceanLower Atmosphere Study) and iLEAPS (the Integrated Land Ecosystem-Atmosphere Processes Study). IGAC, SOLAS and iLEAPS are all now core projects within ISC's Future Earth $^{4}$, which has succeeded IGBP. Some of the leading scientists in this research area in the mid-20th century and latter half of the 20th century included Christian Junge (Germany and USA); Bert Bolin, Henning Rodhe and Erik Eriksson (all Sweden); Paul Crutzen (the Netherlands and Germany); C. David Keeling, Lester Machta, F. Sherwood Rowland, Robert Duce and Robert Charlson (all USA); Mario Molina (Mexico and USA); Hans-Walter Georgii and Dieter Ehhalt (both Germany); Sean Twomey and Ian Galbally (both Australia); and Davendra Lal (India).

iCACGP's efforts are now especially focused on how atmospheric composition and deposition of various pollutants interface with and affect such basic societal issues as water supply and quality, food production, and human and ecosystem health in a changing climate. With the world population growing rapidly, urbanization increasing, forest fires becoming more intense and dependence continuing on sources of energy that pollute the atmosphere, understanding how to ensure a healthy atmosphere has become a very wide ranging research area and a challenge of existential importance for science and society as the Anthropocene evolves.

A celebration of the 60th anniversary of the commission's creation was held at the recent joint 14th iCACGP quadrennial symposium and 15th IGAC science conference (http: //icacgp-igac2018.org, last access: 25 January 2019), which brought together $\sim 700$ participants in Takamatsu, Japan. This gathering exemplified the scientific respect and organizational strength of the IAMAS commissions. The Japanese hosts underscored the importance of existing international organizations in promoting the development of a nation's scientific community, as has happened, for example, for atmospheric chemistry in Japan over the past several decades.

\subsection{International Commission on Polar Meteorology}

In the late 19th and early 20th centuries, explorers were finally able to reach both poles. The International Polar Years of 1882-1883 and 1932-1933 led to significant advances in understanding, but it was not until the International Geophysical Year (1957-1958) that permanent research and observation stations were established and thereafter permanently manned in the polar regions. Since then, appreciation has grown not only of the importance of what is occurring in polar regions but also of the associated influences that changes in the Arctic and Antarctic have on mid-latitude weather, the global climate and sea level.

\footnotetext{
${ }^{4}$ Information on Future Earth is available at http://www. futureearth.org (last access: 25 January 2019).
} 
Reconstructions of past changes in the polar climate make clear that its climate has changed more than the conditions of any other region, ranging from periods when it was warm enough for palm trees to grow on land areas bordering the Arctic Ocean to cold enough that glacial ice that was a few kilometres thick was piled over continental areas so large that the global sea level was pulled down by over $100 \mathrm{~m}$.

As the 20th century proceeded, airline routes were established across the Arctic, the population in high latitudes grew and the potential for extracting resources was recognized. The International Commission on Polar Meteorology (ICPM) was approved in 1963 to focus research attention on high-latitude meteorology. Leading scientists in this field during the early to mid-20th century included, among others, Albert Crary, Joseph Fletcher and Morton Rubin (USA); Svenn Orvig (Norway and Canada); and Norbert Untersteiner (Austria and USA).

With ongoing human-induced warming causing amplified temperature increases in high latitudes, the Arctic's climate is rapidly changing, with sea ice and snow cover retreating, permafrost thawing, and accelerating mass loss from mountain glaciers and the Antarctic and Greenland ice sheets. In addition to affecting mid-latitude weather, polar changes are influencing the Northern Annular Mode and Southern Annular Mode, affecting seasonal to interannual variability. With so much occurring, the importance of improving understanding of polar meteorology and the consequences for the sea level is essential to provide better estimates of emerging impacts having effects around the world.

\subsection{International Commission on Dynamical Meteorology}

The International Commission on Dynamical Meteorology (ICDM) was approved in 1967. Atmospheric dynamics was an early focus in IAMAS, with a number of experts in this field, including Great Britain's Sir Napier Shaw and Reginald Sutcliffe (most famous for his focus on aviation meteorology, initially for the Royal Air Force activities during World War II), serving as presidents of IAMAS. With modelbased weather forecasting starting to be undertaken by many nations in the 1950s and 1960s, improving and extending forecast skill became a major research challenge, especially after Edward Lorenz (USA) in the early 1960s recognized the inherent chaotic results that emerged as a result of seeking to solve the coupled set of nonlinear equations governing atmospheric behaviour (Lorenz, 1963). Leading scientists in early research in this area included Jacob Bjerknes (Norway and USA; no. 17 in Fig. 2); Carl-Gustaf Rossby (Sweden and USA); Alexander Obukhov (USSR); Joseph Smagorinsky, Jule Charney and Norman Phillips (all USA); Aksel WiinNielsen (Denmark); and Sir Brian Hoskins (UK).

Since ICDM's creation, and with substantial efforts by the national meteorological services, the time horizon for skilful model-based weather forecasts has been extended from a few days to 1-2 weeks. Of particular importance in advancing forecast quality has been ensuring a better conditioning of initial conditions (the primary problem in the early modelling effort by Lewis Richardson; no. 11 in Fig. 2), treating the entire global atmosphere, using a finer scale grid (which has also required shortening the time step of the model), implementing less diffusive numerical schemes, better representing subgrid-scale influences and turbulence (treating nonadiabatic processes that were initially not being included), and dealing with the chaotic behaviour caused by the nonlinear equations using an ensemble simulation approach.

With both more extensive observations and better models, there have also been significant advances in the understanding and simulations of not only the global atmosphere but also of the treatment of storms. For example, Schultz et al. (2019) provide a description of how international cooperative activities and exchanges have advanced treatment of extratropical cyclones since the early 20th century. While much attention is given to how the underlying climate is changing, the roles and effects of internal oscillations, ranging from the Madden-Julian Oscillation to Atlantic and Pacific multidecadal oscillations, are currently drawing intense research attention. This is the case both because of how such oscillations affect interannual and interdecadal variations and because of interest in understanding how these oscillations might be influenced by climate change. Improvement of forecast skill at finer spatial scales, nowcasting, better simulation of severe storms and extreme conditions, and greater understanding of apparent cycles and long-term linkages all have the potential to reduce losses of life and improve societal preparation and resilience, so providing exciting challenges for research in dynamical meteorology.

\subsection{International Commission on Climate}

Climate variations and changes have long been of scientific interest because of how they have affected human activities and played a role in determining the prevailing landscape. In proposing that a change in the atmospheric $\mathrm{CO}_{2}$ concentration could have been a cause of changes in Earth's climatic history in the 1890s, Arrhenius also hypothesized that human-caused emissions of $\mathrm{CO}_{2}$ could affect the future climate (Arrhenius, 1896). Fundamental theoretical criticisms of his hypothesis were not resolved by the atmospheric and carbon cycle research communities until the mid-20th century. With the 1960s then becoming relatively cool, recognition that emissions of sulphur dioxide and its conversion to sulphate could also affect the climate broadened inquiry into how the full range of human activities was affecting and could affect past, present and future climates.

The 1970s brought the first analysis of climate change as recorded in ocean-sediment cores (Hays et al., 1976); further studies soon provided records of changes in climate and, through isotopic analyses, the sea level stretching back millions of years. The sediment-core records 
provided initial confirmation of Serbian geophysicist Milutin Milankovitch's hypothesis from the 1930s that glacialinterglacial cycling was being driven by the combined influences of cyclic changes in the ellipticity of the Earth's orbit, tilt of its axis and precession of the orbit through the seasons (Milankovitch, 1941); studies since then have made clear that many additional processes and feedbacks also play a role (Berger, 2001). Leading climate scientists in the early and mid-20th century included, among others, Hubert H. Lamb (UK); Hermann Flohn (Germany); Mikhail Budyko (USSR); Jacques van Mieghem and André Berger (Belgium); José Peixoto (Portugal); Ye Duzheng (China); and Jerome Namias, Victor Starr, Barry Saltzmann and W. Lawrence Gates (all USA).

To provide a focus for the growing international community of climate researchers, IAMAS established the International Commission on Climate (ICCL) in 1977, with its scope set broadly to include the characteristics, fluctuations and changes in climate on all timescales, covering the past, present and future. Two years later, the first World Climate Conference, organized primarily by WMO (1979), led to establishment of WCRP, which has since then provided a framework for bringing together the research capabilities and interests of individual scientists, organized government agency and laboratory research activities.

In response to concerns regarding ongoing increases in fossil-fuel emissions (e.g. Study of Man's Impact on Climate, 1971; WMO et al., 1985), the Intergovernmental Panel on Climate Change (IPCC) was established in 1988 by WMO and the United Nations Environment Programme (UNEP; later joined by UNESCO's Intergovernmental Oceanographic Commission) with the goal of periodically summarizing and assessing research findings regarding human-driven effects on climate, consequent impacts on the environment and society, and potential technological and policy options for moderating the projected changes in climate. While science typically advances as it seeks to reconcile and resolve unexpected observations and different interpretations among scientists, the IPCC has succeeded in bringing the international scientific community together to assess and summarize both understanding of and uncertainties regarding climate change, its impacts on society and the environment, and approaches and measures for avoiding "dangerous anthropogenic interference with the climate system" (United Nations Framework Convention on Climate Change, 1992). For its accomplishments and its now five assessments ${ }^{5}$, carried through with participation of many climate scientists, the IPCC was the co-winner of the 2007 Nobel Peace Prize ${ }^{6}$.

\footnotetext{
${ }^{5}$ For access to the IPCC assessments and special reports, see https://www.ipcc.ch/reports/ (last access: 25 January 2019).

${ }^{6}$ The award is described at https://www.nobelprize.org/prizes/ peace/2007/summary/ (last access: 25 January 2019)
}

With fossil fuels currently providing roughly $80 \%$ of the world's energy and human-induced changes in the climate now pushing the global average temperature toward levels higher than observed in many tens of millions of years, research relating to climate variability and change and integrated impact studies are now the subject of numerous meetings and assessments sponsored not only by IAMAS and other associations within IUGG but also by the WCRP, IPCC, and many other national and international programmes and organizations.

\subsection{International Commission on Planetary Atmospheres and their Evolution}

Scientific hypothesizing about the climates of Mars and Venus goes back at least to the discovery of the telescope in the early 17 th century, with science fiction writers speculating on the potential for alien life during the late 19th and early 20th centuries. The establishment of highly capable observatories and careful spectral analyses provided the first scientific insights into the actual compositions of planetary atmospheres. Within a decade of the launch of the first Earth-orbiting satellite in 1957, fly-by missions took satellites past Earth's neighbouring planets with attempts at landing occurring soon thereafter. These missions provided the basis for improving understanding the energy balances and climates over a much wider range of possible conditions, enriching the types of evaluations of model representations of atmospheric composition and processes and confirming the applicability of physical and chemical relationships for explaining resulting features.

The International Commission on Planetary Atmospheres and their Evolution (ICPAE) was established in 1977, emerging as a result of meetings during the early 1970s of the IRC, which was faced with interpreting satellite-based radiation measurements being taken in planetary fly-bys. The scope of ICPAE was set broadly to include study of planetary, cometary and satellite atmospheres and their evolution (including the Earth's atmosphere, when it is considered in the context of atmospheres on other planets). Significant discoveries have included Venus and Mars hosting liquid water on their surfaces in the past, the extreme greenhouse effect on Venus, the many zonal jet streams in alternating directions on Jupiter and Saturn, erupting volcanoes of many kinds on the planets and their moons, and seasonal extremes on Titan with methane rain filling lakes on the surface. Leading scientists in the early studies of planetary atmospheres included Carl Sagan, Joseph Chamberlain, Thomas Donahue, Seymour Hess, James Kasting, Toby Owen and James Pollack (all USA); Donald Hunten (Canada and USA); Richard Goody (UK and USA); and many others.

In addition to ongoing analytic and Earth-based observational studies, ICPAE members have played leading roles in planetary missions exploring atmospheres in all their diverse 
guises, from Pioneer Venus to Venus Express, a multitude of Mars orbiters and landers, and the Voyager Grand Tour of the outer solar system to Galileo and Juno at Jupiter, Cassini at Saturn, and New Horizons' exploration of Pluto's tenuous atmosphere. With the newest satellite-based observatories starting to provide information about the atmospheres of planets orbiting other stars, understanding the compositions and climates of planetary atmospheres and their evolution continues to provide insights into factors that affect the suitability of a planet for supporting life and the types of alterations that might affect this suitability.

\subsection{International Commission on the Middle Atmosphere}

The International Commission on the Middle Atmosphere (ICMA), originally named the International Commission on Meteorology of the Upper Atmosphere, was approved in 1979. It was formed to provide a focus for international cooperation in research relating to the middle atmosphere, which is considered to reach roughly from the tropopause $(\sim 12-$ $18 \mathrm{~km}$, depending on latitude and season) up to the lower thermosphere ( $\sim 90-95 \mathrm{~km})$. The composition and circulation of the layer are strongly affected by the most energetic radiation emitted by the Sun. Fortunately, the absorption of this energetic radiation by the ozone layer in the middle atmosphere protects the lower atmosphere from much of the biologically damaging UV solar radiation and the consequences of solar storms.

The middle atmosphere's composition is coupled to that of the troposphere via exchanges of trace constituents (e.g. water vapour and methane) and also reflects the tropospheric trends introduced by anthropogenic contributions, notably of carbon dioxide and halocarbons. Middle atmospheric composition is also affected by direct emissions from aircraft and rockets and from the rapid injection of material from the most powerful volcanic eruptions. Trends in trace constituents over the last several decades have been linked to significant trends in stratospheric ozone, including the development of the "ozone hole" over the high southern latitudes in spring. Couplings are also dynamic, with conditions in the middle atmosphere affecting circulation in the troposphere on subseasonal to interannual (and possibly decadal and longer) timescales, especially in the mid-latitudes and high latitudes.

Leading scientists as this field developed during the 20th century included Gordon Dobson and Sydney Chapman (both UK); Michael McIntyre (New Zealand and UK); Alan Brewer (Canada and UK); Taroh Matsuno (Japan); Paul Crutzen (the Netherlands and Germany); Guy Brasseur (Belgium, USA and Germany); Colin Hines (Canada and USA); and James Holton, F. Sherwood Rowland, Richard Lindzen and Susan Solomon (all USA). Major international programmes of relevance to ICMA in the recent past include the Middle Atmosphere Program (MAP;
1982-1985) led by SCOSTEP (Scientific Committee on Solar-Terrestrial Physics) and the SPARC (Stratospheretroposphere Processes and their Role in Climate) project (1992-present) led by the WCRP.

\subsection{International Commission on Atmospheric Electricity}

Atmospheric electricity is a field of atmospheric sciences that has a long and rich history, dating back to the time of American diplomat Benjamin Franklin's kite experiment and later to experiments by Lord Kelvin (Scotland and Ireland), Charles T. R. Wilson and Sir George Simpson (both UK), Sir Basil Schonland and D. J. Malan (both South Africa), and, more recently, Bernard Vonnegut and Martin Uman (both USA) among many others. The field deals with the electrical nature of thunderstorms, particularly lightning but also fair-weather electricity, ions and radioactivity in the atmosphere. Lord Kelvin's early interest in the global electrical circuit paved the way for the work at the Carnegie Institution and Wilson's fundamental formative studies (electron runaway, the cloud chamber, global circuit hypothesis, role of electrified shower clouds and electrostatic infrasound) that have many connections with current work.

International meetings under IUGG and IAMAS auspices go back to the mid-20th century, building up a cadre of researchers and providing a forum for expert scientists from around the world. To better focus international collaboration and cooperation, IAMAS approved the International Commission on Atmospheric Electricity (ICAE) in 1989 to supervise, coordinate, and expand upon the conferenceorganizing efforts of the prior committee that had existed. With the growing dependence on electric power grids, lightning physics and protection has become a key area of interest of ICAE, while in recent years the link between climate change and atmospheric electricity has also received much focus. Members of ICAE were also key in the discovery and understanding of upper-atmospheric transient luminous events (TLEs) such as sprites, elves and terrestrial gamma ray bursts (TGFs).

\section{Concluding Remarks}

With respect to the organization of scientific research relating to the Earth system, the year 1919 was one of very significant achievement, setting the stage for very significant advances over the succeeding 100 years and beyond. As World War I ended and a serious flu epidemic waned, the rebirth and expansion of international scientific cooperation to its modern scope began. Observational systems were growing in coverage, and scientific understanding of why changes were occurring expanded. Leading scientists of the time showed exceptional foresight in moving to establish the foundation of the international structure that has carried forward scientific advancement in the century since. While much has 
been learned, the questions for the decades ahead remain as important and daunting as they were 100 years ago, providing a strong and continuing rationale for IAMAS and its 10 commissions to continue to promote international cooperation and advancement.

The IAMAS focus on advancing scientific understanding of the atmosphere has benefited greatly from both active participation of the world community of atmospheric scientists and also from the advances by the broader geosciences community represented within IUGG. With collective gratitude to all who have served and participated in IAMAS over the past 10 decades, IAMAS welcomes all who would join in ongoing and emerging atmospheric and meteorological research. Further information on IAMAS is available at http://www.iamas.org (last access: 25 January 2019).

The multitude of scientific associations, commissions, and similar groupings within and outside of the parenting International Union of Geodesy and Geophysics may appear confusing at times. It reflects, however, the human endeavour to form various cooperating groups and to categorize phenomena arising from the interrelated and transient continua of the solid, liquid and gaseous compartments of the Earth system. Good (2000) reflected in detail about the evolving geophysical scientific disciplines that together form the union called IUGG. Upon IUGG's centennial, may this commemorative article contribute further to a common memory and tradition into the future about personalities and groupings that have dealt scientifically with atmospheric issues during the past century.

Data availability. The bulk of information used in this article is taken from the cited references or the currently active websites. In addition, information was drawn from a number of additional sources, including an article by P. H. Shaw in the Encyclopedia Britannica (15th edition); early meeting reports appearing in Science and The New York Times; appropriation bills printed in the Congressional Record; and historical information provided on the websites of IAMAS, its commissions and the IUGG.

Author contributions. MCM sought out and assembled much of the historical information in the text and prepared the first and subsequent drafts. HV added to the historical text; participated in revisions of the text; and collected the information in Figs. 1 and 2 and the portraits in Figs. 3 and 4 as well as the contents of Tables 2 and 3 .

Competing interests. The authors are past officers of IAMAS. The authors declare that they have no conflict of interest.

Special issue statement. This article is part of the special issue "The International Union of Geodesy and Geophysics: from differ- ent spheres to a common globe" (https://www.hist-geo-space-sci. net/special_issue996.html). It is not associated with a conference.

Acknowledgements. Discussions with representatives of the American Geophysical Union and American Meteorological Society and comments and suggestions from two reviewers, present and past officers of IAMAS, and its Commissions were helpful and appreciated. We are also grateful to Alik Ismail-Zadeh, Secretary General of IUGG, and to Kristian Schlegel, executive editor of the History of Geo- and Space Sciences, for the organisation of the HGSS special issue at the occasion of the centenary of IUGG and its associations.

Edited by: Jo Ann Joselyn

Reviewed by: Tom Beer and one anonymous referee

\section{References}

Allison, I., Fierz, C., Hock, Mackintosh, R. A., Kaser, G., and Nussbaumer, S. U.: IACS: past, present, and future of the International Association of Cryospheric Sciences, Hist. Geo Space Sci., 10, this special issue, available at: https://www.hist-geo-space-sci. net/special_issue996.html, 2019.

Arrhenius, S.: On the influence of carbonic acid in the air upon the temperature of the ground, Philos. Mag., 41, 237-276, 1896.

Bauer, L. A.: Geophysics at the Brussels meetings, July 18-28, 1919, Science, 50, 399-403, https://doi.org/10.1126/science.50.1296.399, 1919a.

Bauer, L. A.: Meeting of International Union of Geodesy and Geophysics at Brussels, July 18-28, 1919, Mon. Weather Rev., 47, 449-450, https://doi.org/10.1175/15200493(1919)47<449b:MOIUOG>2.0.CO;2, 1919b.

Berger, A.: The role of $\mathrm{CO}_{2}$, sea-level and vegetation during the Milankovitch-forced glacial-interglacial cycles, in: GeosphereBiosphere Interactions and Climate, 119-146, edited by: Bengtsson, L. and Hammer, C. U., Cambridge University Press, Cambridge, UK, 2001.

Bojkov, R.: International Ozone Commission: History and activities, IAMAS Publication Series No. 2, ISBN 978-3-00038600-8, iv + 100 pp., available at: http://www.iamas.org/Pdfs/ IAMAS-PubSer-No2.pdf (last access: 25 January 2019), 2012.

Bolle, H.-J.: International Radiation Commissions: Research into atmospheric radiation from IMO to IAMAS, IAMAS Publication Series No. 1, ISBN 978-3-00-024666-1, iv + 141 pp., available at: http://www.iamas.org/Pdfs/IAMAS-PubSer-No1.pdf (last access: 25 January 2019), 2008.

Cornu, A.: Observations de las limitie ultra-violette du spectre solaire à diverses altitudes, C. R. Acad. Sci. Paris, 89, 808-814, 1879.

Davies, A. (Ed.): Forty years of progress and achievement. A historical review of WMO, Geneva, WMO-No. 21, ISBN 92-6310721-1, viii + 205 pp., available at: http://library.wmo.int/pmb_ ged/wmo_721_en.pdf (last access: 25 January 2019), 1990.

Fourier, J.: Annales de chimie et du physique, Annals of Chemistry and Physics, 27, 236-281, 1824.

Fourier, J.: Mémoire sur la température du globe terrestre et des espaces planétaires, Memoirs of the Royal Academy of Sciences of the Institut de France, 7, 569-604, 1827. 
Gold, E.: Meeting of the International Commission for the Scientific Investigation of the Upper Air, at Bergen, Meteorol. Mag., 56, 215-217, 1921.

Good, G. A.: The assembly of geophysics: Scientific disciplines as frameworks of consensus, Stud Hist. Phil. Mod. Phys., 31, 259292, https://doi.org/10.1016/S1355-2198(00)00018-6, 2000.

Hartley, W.: On the absorption of solar rays by atmospheric ozone, Chem. Soc. J., 39, 111-128, 1880.

Hays, J. D., Imbrie, J., and Shackleton, N. J.: Variations in the Earth's orbit: Pacemaker of the Ice Ages, Science, 194, 11211132, https://doi.org/10.1126/science.194.4270.1121, 1976.

International Meteorological Committee: Atlas International des Nuages/International Cloud-Atlas/Internationaler Wolken-Atlas, Gauthier-Villars et Fils, Paris, 1896.

Ismail-Zadeh, A.: Geoscience international: the role of scientific unions, Hist. Geo Space Sci., 7, 103-123, https://doi.org/10.5194/hgss-7-103-2016, 2016.

Ismail-Zadeh, A. and Joselyn, J. A.: IUGG: beginning, establishment, and early development (1919-1939), Hist. Geo Space Sci., 10, this special issue, available at: https://www. hist-geo-space-sci.net/special_issue996.html, 2019.

Kimball, H. H.: Sessions of the Meteorology Section of the International Union of Geodesy and Geophysics, Rome, Italy, May 4-9, 1922, Mon. Weather Rev., 50, 488, https://doi.org/10.1175/15200493(1922)50<488:SOTMSO>2.0.CO;2, 1922.

Lorenz, E.: Deterministic nonperiodic flow, J. Atmos. Sci., 20, 130-141, https://doi.org/10.1175/15200469(1963)020<0130:DNF>2.0.CO;2, 1963.

Lyell, C.: Principles of Geology, Being an Attempt to Explain the Former Changes of the Earth's Surface, by Reference to Causes now in Operation, John Murray, London, vol. 1, 1830.

Lyell, C.: Principles of Geology, Being an Attempt to Explain the Former Changes of the Earth's Surface, by Reference to Causes now in Operation, John Murray, London, vol. 2, 1832.

Lyell, C.: Principles of Geology, Being an Attempt to Explain the Former Changes of the Earth's Surface, by Reference to Causes now in Operation, John Murray, London, vol. 3, 1833.

Manabe, S. and Wetherald, R. T.: Thermal equilibrium of the atmosphere with a given distribution of relative humidity, J. Atmos. Sci., 24, 241-259, https://doi.org/10.1175/15200469(1967)024<0241:TEOTAW>2.0.CO;2, 1967.

Mandea, M. and Petrosky, E.: IAGA: a major role in understanding our magnetic planet, Hist. Geo Space Sci., 10, this special issue, available at: https://www.hist-geo-space-sci.net/special_ issue996.html, 2019.

Meetham, A. R.: Conference on atmospheric ozone, Oxford: September 9th-11th, 1936, Meteorol. Mag., 71, 201-205, 1936.

Milankovitch, M.: Kanon der Erdbestrahlung und seine Anwendung auf das Eiszeitproblem, Serbian Academy of Science, Belgrade, 633 pp., 1941.

Ohring, G., Bojkov, R. D., Bolle, H.-J., Hudson, R. D., and Volkert, H.: Radiation and ozone: catalysts for advancing international atmospheric science programs for over half a century, B. Am. Meteorol. Soc., 90, 1669-1681, https://doi.org/10.1175/2009BAMS2766.1, 2009.

Revelle, R. and Seuss, H. E.: Carbon dioxide exchange between atmosphere and ocean and the question of an increase of atmospheric $\mathrm{CO}_{2}$ during the past decades, Tellus, 9, 18-27, 1957.
Richardson, L. F.: Weather Prediction by Numerical Process, Cambridge University Press, London, 1922, reprinted by Dover, New York, 1965.

Rosbjerg, D. and Rodda, J.: IAHS: a brief history of hydrology, Hist. Geo Space Sci., 10, this special issue, available at: https: //www.hist-geo-space-sci.net/special_issue996.html, 2019.

Schereschewsky, P. L.: "Afterword", in: The development and status of modern weather prediction, edited by: Reed, R. J., B. Am. Meteorol. Soc., 58, 400-401, https://doi.org/10.1175/15200477(1977)058<0390:BMLTDA>2.0.CO;2, 1977.

Schultz, D. M., Bosart, L. F., Colle, B. A., Davies, H. C., Dearden, C., Keyser, D., Martius, O., Roebber, P. J., Steenburgh, W. J., Volkert, H., and Winters, A. C.: Extratropical Cyclones: A century of research on meteorology's centerpiece, Meteorol. Monographs, 59, 16.1-16.56, https://doi.org/10.1175/AMSMONOGRAPHS-D-18-0015.1, 2019.

Schuster, A.: International science organization, Science, 53, 364367, https://doi.org/10.1126/science.53.1372.364-b, 1921.

Shaw, W. N.: The Meteorological Section of the Geodetic and Geophysical Union, Q. J. Roy. Meteor. Soc., 49, 23-33, https://doi.org/10.1002/qj.49704920507, 1923.

Smythe-Wright, D., Gould, J., McDougall, T., Sparnocchia, S., and Woodworth, P.: IAPSO: tales from the ocean frontier, Hist. Geo Space Sci., 10, this special issue, available at: https://www. hist-geo-space-sci.net/special_issue996.html, 2019.

Study of Man's Impact on Climate (SMIC): Inadvertent Climate Modification: Report of the Study of Man's Impact on Climate (SMIC), MIT Press, Cambridge, Massachusetts, 308 pp., 1971.

Tyndall, J.: On the Absorption and Radiation of Heat by Gases and Vapours, and on the Physical Connexion of Radiation, Absorption, and Conduction, Philos. T. Roy. Soc. London, 151, 1-36, https://doi.org/10.1098/rstl.1861.0001, 1861.

United Nations Framework Convention on Climate Change (UNFCCC): United Nations Framework Convention on Climate Change, 25 pp., 1992, available at: https://unfccc.int/resource/ docs/convkp/conveng.pdf (last access: 25 January 2019).

Volkert, H.: Putting faces to names: snapshots of two committee meetings, 95 years apart, emphasize continuous international cooperation in the atmospheric sciences, Adv. Atmos. Sci., 34, 571-575, https://doi.org/10.1007/s00376-017-6329-6, 2017.

Wood, H. O.: Organization of the American Geophysical Union, Science, 51, 297-299, https://doi.org/10.1126/science.51.1316.297-a, 1920.

World Meteorological Organization: Proceedings of the World Climate Conference - a conference of experts on climate and Mankind, Geneva, WMO No. 537, ISBN 92-63-10537-5, xii + 791 pp., 1979.

World Meteorological Organization (WMO), United Nations Environment Programme (UNEP), and International Council of Scientific Unions (ICSU): Report of the International Conference on the Assessment of the Role of Carbon Dioxide and of Other Greenhouse Gases in Climate Variations and Associated Impacts, WMO Publication no. 661, Geneva, available at: https://library.wmo.int/pmb_ged/wmo_661_en.pdf (last access: 25 January 2019), 1985. 